\title{
'The recounting of a life is a cheat': Unreliable narration and fragmentary memory in historical fiction
}

\begin{abstract}
:
It is well known that fiction can be used to narrate the lives and experiences of those who have been marginalised within, or by, historical discourse. However, is revealing or recuperating the past the most authentic way to write narratives about those people whom history has forgotten? As writers, how can we use fiction to tell the lives of those people whose stories have effectively been lost, silenced or omitted from public archive and personal recollection? And, more personally, how can we write stories about people in our own past if we have been prohibited from telling them?

This paper examines ways in which fiction can illuminate the presence of loss in ways which historical discourse cannot. Drawing on the creative component of my PhD, as well as from the work of novelist Carol Shields and theorist Nicola King, I will suggest that we can write about the past in ways which prompt readers to reflect upon why certain traumatic or shameful details might be withheld within a fictional text. In my own creative work, 'The Other Side of Silence' (Kon-yu 2009) my protagonists' refusal to remember the past in a complete or coherent manner suggests that while some suppressed histories cannot ever be told, the effect that they have on the characters can still be clearly shown within the text.
\end{abstract}

Keywords: memory, silence, fiction

\section{Representing the past in fiction}

'[W]here history says little,' Anna Laetitia Barbauld wrote in 1810, 'fiction might say much' (Tuite 2005: 248). It is only after writing both the creative component of my $\mathrm{PhD}$ and the accompanying exegesis that $\mathrm{I}$ have come to understand the complexities of Barbauld's statement. Fiction might say much more about women's history, dealing as it does with imagination rather than fact, but it also might not say the things I had imagined it could. My PhD was motivated, at first, by a desire to tell the story of a particular woman in my family's history, a woman I had only heard about in hushed tones. A woman whose past, it seemed, was so terrible that her story had become silenced within the official version of my family's history. I couldn't understand why the details of this woman's life should still be obscured, and I wanted to take her out of the shroud of silence that surrounded her and write her story. I began the project searching for the facts about this woman's life. However, I soon learnt that those who knew her story did not want to recount it in full and although certain aspects of her life were revealed by people in my family, others were kept staunchly silent. Of course the tid-bits I had gathered made her more intriguing. What could this woman possibly have done to deserve this shame which worked its way down through successive generations? Unable to garner information about her anecdotally, I searched for her in archives. But here 
again, I was met with silence. There seemed to be no records of her anywhere, no way in which I could trace the details of her life.

The silencing of women's lives due to shame has been articulated by feminist scholars, biographers and memoirists. In her essay, 'Narrative Hunger and the Overflowing Cupboard', novelist Carol Shields suggests that:

Enormous quantities of stories - perhaps the finest stories of our culture - have been lost to illiteracy or lack of permission... a prohibition placed on the story teller - most often: 'Woman hold thy tongue!' (Shields 2003: 26)

The problems I'd had in locating my ancestor's life through archival material had been faced by many writers interested in women's history. (These issues are, of course, pertinent to many 'ordinary' men's histories.) In their article 'Hystorical fictions', Ann Heilmann and Mark Llewellyn state that:

The closing decades of the twentieth century and first years of the new millennium have seen a growing trend towards historical fiction in women's writing. (Heilmann \& Llewellyn 2004: 137)

Writers such as Margaret Atwood, AS Byatt, Margaret Forster, Maxine Hong Kingston, Drusilla Modjeska, Carol Shields, Toni Morrison, Amy Tan, and Jeanette Winterson, to name a few, have all written fiction about women's lives set in the past. These novels encompass the infamous, such as Margaret Atwood's Alias Grace (1996) and Toni Morrison's Beloved (1987), as well as the 'ordinary,' such as Poppy in Drusilla Modjeska's fictional memoir Poppy (1990), or Winnie in Amy Tan's novel The Kitchen God's Wife (1991). The difficulties of writing women's history in fiction is a large and welldocumented one and is dealt with in more detail in a previous paper, 'Letting go of the truth: researching and writing the other side of silence in women's lives' (Kon-yu 2010).

In the broadest sense texts such as those listed above, use fiction to tell stories about women whose narratives have previously been misrepresented or marginalised within our culture, although they vary greatly in both form and style. The texts also vary in how they deal with the past, or with stories about the past that have long been suppressed by the various characters. For example, Morrison's Beloved and Tan's The Kitchen God's Wife are similar insofar as they feature characters engaging in their own recollections of the past, but do so in radically different ways. The Kitchen God's Wife is based loosely on the life story of Tan's mother, and in the book it is the protagonist, Pearl's mother, Winnie, who relays the events of her own past to her daughter. Incredibly, Winnie tells the story in a single sitting, without interruption from Pearl. The traumatic events of her past are laid out unproblematically, in chronological order, and Winnie never doubts her memories, or her ability to recall the past in detail. In contrast, in Beloved the past is not represented so coherently. Instead the past has become a succession of dream-like stories, which are told and retold so often by the central characters - Sethe, Denver, Paul D and Baby Suggs - that the lines between fact and fiction become difficult to decipher, even for those characters telling stories about their own experiences. The secret that Sethe is keeping from Paul D - that she murdered her daughter and nearly killed her sons - is told three times, from three different perspectives, with Sethe being the last character to relay the story. Even as she does so, Sethe circles around the details, as she physically spins around the room. 
It is almost unfair to compare any novel to Beloved, which seeks to re-cast the infamous story of the slave-woman, Margaret Garner, who killed her children in order to save them from slavery (see Margaronis 2008). Morrison's novel is ambitious in scope, and while it has obvious feminist themes, it is a powerful re-imaging of the lives of slaves, and a tribute to the 'Sixty Million and More' lives lost through slavery. Tan's novel was closer to my own project in that it seeks to re-frame the life of an ordinary woman by telling her story. Huntley argues that:

In writing Winnie's life, Amy Tan exposes the layers of silence under which are buried the forgotten stories of women like Winnie - like Tan's own mother. As Winnie recounts her story in the novel, she shapes and thus reclaims her life, breaking the long silence that has marked her existence... (Huntley 1998:

However, in this text Winnie lays bare the bones of her life in a way that suggests that well-kept secrets are temporary and can simply be retrieved and recorded. Inspired as I was by Tan's focus on ordinary women's histories, as a writer I was concerned that a text which followed a trajectory of confession and revelation might perpetuate the myth that women's lives can simply be retraced and revealed. Given the real constraints I had faced in finding details about my ancestor, as well as my desire not to cause shame to family be revealing those details I did know, I felt that I couldn't write an historical fiction which 'filled in' the secret or shameful aspects of her story. In an attempt not to 'hold my tongue' I began to think about other ways in which I might write about a woman, like my relative, whose story could not be told. I wanted my fiction to reflect both the lack of information about my ancestor's life and the prohibition I had placed on myself not to use the scant facts of her real life in my manuscript.

\section{Reading loss}

In Woman, Native, Other T Minh-ha Trinh emphasises the necessity of highlighting the silences and omissions in women's narratives. She states:

Silence as a refusal to partake in the story does sometimes provide us with a means to gain a hearing. It is a voice, a mode of uttering, and a response in its own right. Without other silences, however, my silence goes unheard, unnoticed; it is simply one voice less, or more point given to the silencers. (Trinh 1989: 83)

While Trinh is a documentary maker and ethnographer, her insights are relevant to what I wanted to achieve in my fiction. I realised that not revealing the shameful aspects of my character's past might be a more authentic way to narrate her story, as it was precisely those kinds of shameful secrets which created the silence around the details of my ancestor's life. As a writer, I could demonstrate how the past could still have an impact on my fictional characters' lives, without having to reveal the kinds of details that I hadn't been able to ascertain or didn't want to speak of. While many of the texts I mentioned earlier deal with women's histories in a number of ways, most of them do recover the past, or recuperate the stories that have been suppressed for so long. This led me to research other ways of writing; and to think about how fiction can be used to show the presence of loss in ways that history cannot. As Maurice Blanchot writes in The Writing of the Disaster 'Wittgenstein's 
"mysticism"... must come from his believing that one cannot show when one cannot speak. But without language, nothing can be shown' (Blanchot 1986: 10-11). What resonates for me in Blanchot's book is the idea that writing narratives about traumatic or shameful events is necessary, but the way in which writers do so must alter to reflect the impact of the trauma or shame.

The question about how to write women's histories in fiction has been faced by many writers. Virginia Woolf is well known for her attentiveness to the liminal or the marginal in her female characters' lives, and I would argue that her work is still of interest to contemporary feminist writers grappling with these issues. For example, Lyn Pykett argues:

It would be wrong to see Woolf as wishing simply to recuperate the Arnoldian project of seeing things steadily and seeing them whole, but there are a number of occasions on which she seemed to express a preference for a fictional method that would (as it were) see the fragments of experience in all their fragmentary and evanescent detail and yet still see them whole. (Pykett 1995: 98)

As Gabrielle McIntire suggests:

The effects of recollection and the remembered historical on the familial, individual and communal are central subjects of almost every one of Woolf's novels. (McIntire 2008: 187)

Other writers have followed Woolf's example of fragmentation, situated narrators and a lack of formal closure in telling women's stories. Wendy Roy writes that Carol Shields' novels 'emphasize the inadequacy, and yet the necessity, of portraying a woman through gaps in her life story' (Roy 2003: 124-125). For example, Shields' novel The Stone Diaries tells the story of Daisy Goodwill Flett. The book is seemingly structured as autobiography, yet tends to omit certain events which would traditionally be defined as critical, foregrounding instead those that might be read as insignificant in the writing of a life. Seemingly trivial incidents are described in great detail: for instance, Daisy's cooking of a jellied veal loaf is given more than three pages (1994: 157-160), while, by contrast, her marriage to Barker Flett is described in one relatively short paragraph (1994: 153). The account of her first wedding, rather than focusing on Daisy and her husband, Harold Hoad, concentrates instead on her father's speech, and recalls in great detail another speech delivered by Cuyler at Daisy's graduation ceremony (1994: 80-86). The traumatic death of her first husband is skimmed over, as are the circumstances of her marriage to her second husband and birth of her three children; yet twenty pages are given over to letters written in response to Daisy's newspaper column, 'Mrs. Green Thumb'(1994: 205-225).

By not prioritising the details we would expect in this kind of narrative, The Stone Diaries asks questions about just what is significant in the recounting of a life. As Winifred M Mellor remarks, 'The manipulation of narrative technique in the text draws attention to the way women are silenced by the restrictive modes of certain genres' (Mellor 1995: 97). The Stone Diaries refutes the narrative conventions of traditional realism, suggesting that it is these conventions, with their emphasis on action, revelation and closure that have led to the silencing or marginalisation of women's stories. As Roy writes, 'Shields has described her fictive autobiography as a comment on women's silencing and on their erasure from the centre of their own lives' (2003: 138). As Daisy herself points out, 'The recounting of a life is a cheat, of course; I admit the truth of this; even our own stories are obscenely distorted' (2003: 
28). Despite the silences, which Shields draws our attention to with her pseudoautobiographical structure, as well as Daisy's own distorted take on events, this book nonetheless gives an expansive picture of the life of Daisy Goodwill Flett.

Like The Stone Diaries, Shields' last novel Unless also questions what is relevant or important when writing about a woman's life. In this text the protagonist's daughter is silenced throughout the novel. Reta's eldest child Norah has dropped out of university to sit on a street-corner wearing a sign with the word GOODNESS written on it, and the reason why provides a hook into the narrative of the text. It is impossible to read the novel without wondering why Norah has taken this stance and whether or not she will return to her 'normal' existence. Yet Shields does not give the reader a conclusive explanation for Norah's actions. Throughout the novel Reta speculates on a number of possible reasons for her daughter's silent protest. It might be the result of Norah's argument with her English professor about Madame Bovary (Shields 2002: 217), or, as Reta's partner Tom believes, Norah may be suffering from post-traumatic stress disorder. What is evident at the end of Unless is that, unlike Tan, Shields does not provide the reader with a definitive explanation for Norah's silence. Shields resists the temptation of giving us the story of Norah's life thus far, and although we are given some insights into Norah's past, these insights do not answer the ultimate question about Norah's current stance. Like Tan, Shields has the opportunity to unravel the mysteries that remain about Norah's behaviour; after all, in the book's final paragraph, Norah is 'recovering at home... and shyly planning her way on a conjectural map' (2002: 320). And we must not forget that this is a fictional world, a place in which anything, within realist limits, could happen, where facts could be revealed and closure attained once and for all. Yet I believe this resisting of closure is not incidental. By setting up Norah's silence and refusing to fill it with words of explanation or resolution at the text's conclusion, Shields' novel offers an exposure of the convention of the realist fictional goal of reaching a singular conclusion or meaning. In refusing to reveal the "true" cause of Norah's actions the text implies that such "truths" are perhaps unattainable due to their subjective, rather than definitive, nature.

\section{Writing loss}

While not historical fictions themselves, both The Stone Diaries and Unless critique notions of confession and closure - notions which much historical fiction about women rely upon. Both texts also point out that the 'truth' about their characters' lives might be reductive, and the search for that truth, might itself be misguided. Given the gaps in my ancestor's story, Shields' approach to showing, but not telling, the lives of her characters was useful to me as a writer of fiction. Shields' use of unreliable narrators was also influential and I could see the benefit of focalising my own narrative through a single subjective perspective. I was interested by the way Shields' character Reta, the narrator of Unless, managed to say so much about Norah, while Norah said so little.

I decided, then, to write a narrative which centred on the relationship between mother and daughter. In the text, I would write from the perspective of Alba, a young Italian woman who, throughout the narrative, would only reveal information selectively about her mother, Serafina. The story would begin with Alba on a boat bound for Australia, leaving her extended family behind in the small city of Salerno. My intention was to keep Italy firmly in the past, thereby keeping Alba's life there shrouded in mystery. Although Alba was the eyes and ears of the narrative, it was Serafina's life I wanted to pay attention to, as Serafina, in my mind, most closely resembled my own silenced ancestor. Like 
my ancestor, Serafina was the character whose story hinted at something dramatic in her past, something which Alba refused to speak of. Serafina, then, became a character seen only through other characters' eyes. There is a vast amount of information readily available to those interested in Italian migration to Australia, and Loretta Baldassar writes that 'thousands of Italians... [immigrated] in the immediate post-World War II period' (Baldassar 2004: 268). Alba's journey to Australia was easy enough to research. But how accessible would information be about a woman like Serafina? Especially given that neither common-law relationships nor divorce, for instance, were recorded by the church. This was exactly the kind of life I did not want to presume to know too much about.

Yet, confined by only being able to see Serafina through Alba's eyes, my narrative began to stall. I became less interested in Alba and the relentless inching forward of her new life. I realised that by denying Serafina a voice, I had become preoccupied with the miniscule details of Alba's day to day existence, and my text seemed to be more of an historical account of migrant women in Australia than anything else. Even though I wanted to maintain some silence around Serafina's life, I found that I had the wrong kind of silence. I decided that I had to approach Serafina's history in a different way. The silencing of Serafina's story was still very much the crux of my text, but I wanted to creatively explore different ways of writing about her past.

\section{Remembering reluctantly: another attempt}

This narrative dead-end led me back to more research, and I began to think about Trinh's idea of multiple silences. I also began to think about how writers of historical fiction about women, such as Tan and Morrison, had used memory as an important tool for getting into characters' pasts. In her text Memory, Narrative and Identity: Remembering the Self, Nicola King suggests that there are two main approaches to remembering the past. She refers to Freud's model of an 'archaeological excavation' which 'assumes the past still exists "'somewhere" waiting to be rediscovered' (King 2000: 4). King goes on to define the second mode of remembering as 'one of continuous revision or "retranslation," reworking memory-traces in the light of later knowledge' (2000: 4). King applies these ideas to literary fiction to show how novels can challenge the Freudian model of 'excavation', and I realised that in my creative draft, there existed the implicit belief that the 'past' was still intact somewhere (in this particular version, the past was in Italy, and still remained 'a mystery'). For me, King's notion of revision and re-translation pointed to a different way that I might write about the past and still not have to give away the sordid or scandalous details I had decided to suppress.

I made a decision then to set the early part of the narrative in Italy, thereby allowing Serafina a voice within the text. I retained a subjective voice for both characters and this allowed me to write each character's recollection of events differently. Since I wanted to include Serafina in the narrative without suggesting that lives like hers were traceable in any archival, historical sense or even reachable through the back alleys of history (those ways in which we traditionally find out about women's lives) - I made sure to eradicate all diaries and letters. It was easy to suggest that Serafina was illiterate, given the time in which she was born, her gender and her lower-class status. I obscured details about Serafina's past, especially those events one wouldn't be able to find out when researching the life of such a woman. Instead I chose to focus on the relationship between Serafina and Alba, and the way in which their incomplete memories might evoke for the reader a sense of all that cannot be known. 
Therefore, the memories of individual characters (Alba and Serafina) became the means by which I could challenge the notion of a history lying in wait to be exhumed.

Given the inclusion of Serafina's narrative, I decided to re-write significant portions of the creative text with the intention of forcing Alba to remember events in her past, especially those episodes she would rather forget. Even though the narrative follows Alba to Australia, depriving Serafina of a voice in the latter part of the text, Serafina is still present in Alba's memories. Alba's inability to forget the past strikes me as reminiscent of the way in which writers (notably Woolf) articulate the past in their novels. McIntire posits that writers such as Woolf (and TS Eliot):

Write out a past that can never be mastered, that is always ajar, and open to both re-inscription and re-experience - open to the supplement of perpetual (re)turn... (2008: 7)

By including Serafina as a narrator in the early part of the text, I was able to not only draw a distinction between how these characters remembered, I was also able to show the discrepancies between the memories themselves. The past became more prevalent in the text, and was thus open to the kind of 'reinscription and re-experience' which McIntire mentions. Additionally, in this version of the text, memory is congruent with King's definition, cited above, 'as one of continuous revision' (2000: 4). Although 'The other side of silence'moves in a linear trajectory, the frequent analepses (or flashbacks) serve to destabilise the notion of chronology within the text, further emphasising the role that the past plays in the present lives of these two characters.

In writing part of the text from the perspective of two different characters, I was providing the reader with multiple, often conflicting, versions of the past. I did not want to reveal the details of the characters' lives which would have been silenced due to shame, but, instead, wrote memories surrounding these events. For example, in Chapter Three, the narrative is focalised through Serafina's perspective and the character remembers one of the last evenings before they are expelled from Alba's father's house. She recalls:

There had been no sounds out of the ordinary. Serafina had been poised for a shriek, a sudden scraping of a chair from the table. Raised voices. But there was nothing. He hadn't told Alba then, she'd thought, scrubbing the pot with vicious intensity. One more thing he had left for her to do. (2009: 21)

Serafina later approaches Alba's bedroom. She reaches forward to knock on the door, but cannot do it; nor does she ever explain to Alba the reasons why they have to move.

Later in the text, I return to the memory of this night, but this time the event is focalised through Alba's perspective. In her memory of this night, the character focuses on seemingly insignificant things: the conversation at the dinner table, the French lesson she'd had that day, her desire to brush her hair one hundred times in an attempt to make it straight. Alba also recalls being in her room and hearing footsteps coming towards her door, and she assumes that these belong to her father. Years later, Alba does not question to whom those footsteps might have belonged, but she does question whether or not she actually heard them, 'Looking back, she cannot be certain that she didn't plant those footsteps there herself, that she hasn't imagined them because the alternative is still too painful to bear' (2009: 146-7). Alba wants to believe that her father wanted to say good-bye, and so the footsteps loom large in Alba's memory. Alba does not 
consider that it might have been her mother outside her room. King poignantly articulates this process of modifying the past:

We long for a time when we didn't know what was going to happen next - or, conversely, to relive the past with the foreknowledge we then lacked. (2000: 2)

King suggests that trauma may inhibit characters from experiencing their memories fully (see Kearney 1998 and Mitchell 2002). In 'The other side of silence', Alba is unable to recall the last night she spent with her father without wondering: 'Where were they then? The hints of things to come?' (2009: 46). Conversely, she expresses grief over her ignorance on that evening:

There is something about the certainty of those brush strokes, the way she kept on going, which Alba cannot bear to recall. There had been, in the flex and stretch of Alba's arm, no apprehension that things were about to change. (2009: 145)

In writing accounts of this night from both characters' perspectives, I wanted to emphasise that the meaning which might be created from past events is necessarily fragmentary, contradictory and partial. I also wanted to suggest that shame about the past suppresses certain stories from ever being narrated, or results in the emergence of other stories, differently positioned.

As the text progresses, Alba's memories become more uncertain. Thus, the character is not only questioning her past as the story moves forward, and by extension Serafina's past, but Alba's constant speculation means that she is unreliable in providing the kind of 'truth' that much historical fiction depends upon. Alba begins revising her history by making her memories more palatable. Serafina's history is thus doubly marginalised within the narrative: not only by her daughter's migration to Australia, but by the ways Alba chooses to remember her and forget her. As Shields reminds us in The Stone Diaries, 'a childhood is what anyone wants to remember of it. It leaves behind no fossils...' (Shields 1994: 148).

Thus, even though the particulars of Serafina's life - events significant enough to provoke the expulsion from Alba's father's house are not made explicit in 'The other side of silence,'they nonetheless haunt the narrative. The text leaves space for the various interpretations of what may have happened in Serafina's life, and it is for the reader to decide what these events could have been, or if they need to be speculated about. Inevitably a sense of loss permeates the novel - most obviously, the loss of Serafina's history. Yet, what I hope is evident is the way in which the past remains present in the lives of these two characters, even if it cannot be wholly articulated. The reader expecting confession or disclosure will be frustrated by the loss of Serafina's history in 'The other side of silence'. In a sense, the reader's frustration at this loss reflects my own frustration at the loss or deliberate silencing of stories about women such as my ancestor.

Wendy Roy (2003: 124-5) writes about The Stone Diaries that it 'emphasizes the inadequacy, and yet the necessity, of portraying a woman through gaps in her life story'. I have come to realise that, even within fiction, a writer needs to think differently when trying to write stories about women like my ancestor. If I had left Serafina's character in the past, I would have been suggesting that the past is a place that can be reached, if only one has the right equipment. I would be adhering to the promises offered by excavation, which, paradoxically, leaves so many women's lives buried. In using memory to help structure the narrative, however, I have illustrated that the past can be articulated in fragments, and 
that its inconsistencies arise from each character's version of events. By withholding details and not offering a complete fictional history for Serafina, I have been able to critique how problematic that notion is. I have not told the 'truth' about Serafina's past, but by using highly subjective narration and offering contradictory memories, I have tried, instead, to show how her past is a difficult one to articulate because of the shame associated with it. I want to suggest that even though this character, like my own ancestor, has a past that cannot simply be told, her life should be remembered, however faulty or fragmented the memories might be.

\section{Works cited}

Atwood, M 1996 Alias Grace, Bloomsbury, London return to text

Baldassar, L 2001 Visits Home: Migration Experiences between Italy and Australia, Melbourne UP, Carlton South, Vic return to text

Blanchot, M 1986 The Writing of the Disaster, trans. Ann Smock, University of Nebraska Press, Lincoln return to text

Byatt, AS 1990 Possession: A Romance, Chatto \& Windus, London return to text

Forster, M 1996 Hidden Lives: A Family Memoir, Penguin, London return to text

Heilmann, A \& M Llewellyn 2004 'Hystorical fictions: women (re)writing and (re)reading history', Women: A Cultural Review 15, 2: 137-249 return to text

Hong Kingston, M 1977 The Woman Warrior: Memoirs of a Girlhood Among Ghosts, Allen Lane, London return to text

Huntley, ED 1998 Amy Tan: A Critical Companion, Critical Companions to Popular Contemporary Writers, Greenwood Press, Westport, CT return to text

Kearney, R 1998 'Remembering the past: the question of narrative identity' Philosophy and Social Criticism 24: 49-60 return to text

King, N 2000 Memory, Narrative, Identity: Remembering the Self, Edinburgh University Press, Edinburgh return to text

Kon-yu, N 2009. The Other Side of Silence; using fiction to explore the resources and limitations in writing about women's lives, $\mathrm{PhD}$ thesis available at: http://researchrepository.murdoch.edu.au/4262/ return to text

Kon-yu, N 2010 'Letting Go of the Truth; the Other Side of Silence in Researching Women's Lives', TEXT: Journal of Writing and Writing Courses 14, 2 http://www.textjournal.com.au/oct10/konyu.htm return to text

Mantel, H 2008 Wolf hall, Fourth Estate, London

Margaronis, M 2008 'The Anxiety of Authenticity: Writing Historical Fiction at the End of the Twentieth Century', History Workshop Journal 65: 138-60 return to text

McIntire, G 2008 Modernism, Memory, and Desire: TS Eliot and Virginia Woolf, Cambridge University Press, Cambridge return to text

Mellor, WM 1995 “"The Simple Container of our Existence”: Narrative Ambiguity in Carol Shields's The Stone Diaries', Studies in Canadian Literature/Etudes en Littérature Canadienne 20, 2: 96-110 return to text

Mitchell, A 2002 The Freedom to Remember: Narrative, Slavery, and Gender in Contemporary Black Women's Fiction, Rutgers University Press, Brunswick NJ return to text

Modjeska, D 1990 Poppy, Penguin, Ringwood, Vic return to text 
Morrison, T 1987 Beloved, Vintage, London return to text

Pykett, L 1995 Engendering Fictions: the English Novel in the Early Twentieth Century, Edward Arnold, London return to text

Roy, W 2003 'Autobiography as critical practice in The Stone Diaries', in E Eden and D Goertz (eds) Carol Shields, Narrative Hunger, and the Possibilities of Fiction, University of Toronto Press, Toronto: 113-146 return to text

Shields, C 1994 The Stone Diaries, Fourth Estate, London return to text

Shields, C 2002 Unless, Fourth Estate, London return to text

Shields, C 2003 'Narrative hunger and the overflowing cupboard', in E Eden and D Goertz (eds) Carol Shields, Narrative Hunger, and the Possibilities of Fiction, University of Toronto Press, Toronto: 19-38 return to text

Tan, A 1991 The Kitchen God's Wife, Flamingo, London return to text

Trinh, TM 1989 Woman, Native, Other: Writing Postcoloniality and Feminism, Indiana University Press, Bloomington, IN return to text

Tuite, C 2005 in B Caine, M Spongberg, and A Curthoys (eds) Companion to Women's Historical Writing, Palgrave Macmillan, Houndsmill return to text

Winterson, J 1989 Sexing the Cherry, Bloomsbury, London return to text

Woolf, V 1929 A Room of One's Own, Hogarth, London

Woolf, V 1967 Collected essays, London: Hogarth

Natalie Kon-yu has a PhD from Murdoch University (WA) and now lives in Melbourne where she lectures at Victoria University in Creative Writing, Gender Studies and Literary Studies. Her manuscript 'The list of missing things' was long-listed for The Australian/Vogel award in 2010, she received an Australian Society of Author's Mentorship for 2011 and is working on the manuscript with Susan Hawthorne of Spinifex Press. Natalie is also working on an anthology of creative non-fiction and fiction about female friendship, which will be published by Pan Macmillan in 2013.

\section{TEXT}

Vol 16 No 1 April 2012

http://www.textjournal.com.au

Editors: Nigel Krauth \& Enza Gandolfo

Text@griffith.edu.au 